\title{
IMPROVEMENT OF ACTIVE LIVER CIRRHOSIS IN PATIENTS MAINTAINED WITH AMINO ACIDS INTRAVENOUSLY AS THE SOURCE OF PROTEIN AND LIPOTROPIC SUBSTANCES ${ }^{1,2}$
}

\author{
By RICHARD D. ECKHARDT,3 WILLIAM W. FALOON, AND \\ CHARLES S. DAVIDSON \\ (From the Thorndike Memorial Laboratory, Second and Fourth Medical Services [Harvard], \\ Boston City Hospital, and the Department of Medicine, Harvard Medical School, Boston)
}

(Received for publication December 6, 1948)

An adequate, nutritious diet is the basic consideration in the treatment of patients with liver disease, particularly cirrhosis (1). However, because of the frequent digestive disturbances encountered in these patients, occasions arise when an adequate intake of nutritious foods cannot be maintained, and complemental or complete nutritional feeding by the intravenous route would appear indicated. Infusions of glucose and vitamins prepared for parenteral use are widely employed, but the desirability of administering protein hydrolysates intravenously to patients with hepatic insufficiency has been the subject of controversy. Thus, it has been stated that amino acids administered parenterally to such patients are not as promptly deaminized and result in a higher incidence of untoward reactions than when administered to normals (2-4), so that "intravenous injection is contraindicated in severe hepatic insufficiency" (5). Nevertheless, since other investigators have been unable to confirm any significant decrease in the rate of deaminization of amino acids following their intravenous injection or any increase in untoward reactions (6-9), parenteral protein hydrolysates have been quite extensively employed as a therapeutic adjunct in the treatment of patients with cirrhosis of the liver and with infectious hepatitis (10-12).

The experiments reported here were undertaken to clarify the controversy regarding the desirability of administering protein hydrolysates pa-

1 The expenses of this investigation were defrayed in part by a grant from Merck and Company, Inc., Rahway, New Jersey, to Harvard University.

2 A preliminary report of this investigation was included in the Proceedings of the Fortieth Annual Meeting of the American Society for Clinical Investigation, May 3, 1948.

3 U. S. Public Health Service Postdoctorate Research Fellow. renterally to patients with liver disease. Observations were made of the clinical tolerance, the metabolism and excretion, and the therapeutic value of a 10 per cent solution of amino acids administered intravenously in amounts of 500 to $1,000 \mathrm{cc}$. daily for from two to four weeks as the sole source of nitrogen and of lipotropic substances to four patients with active cirrhosis of the liver. The results indicate that intravenously administered amino acids are well tolerated by patients with severe liver disease, are metabolized and excreted in a manner differing little from normal, and may promote clinical improvement when administered as the sole source of nitrogen and of lipotropic substances.

\section{MATERIALS AND METHODS}

The clinical and laboratory observations of the four patients with cirrhosis of the liver selected for this study are tabulated in Table I. Each gave a history of longstanding alcoholism and of meager dietary intake. Three of the patients (B. B., W. C., and J. Q.) were deeply jaundiced and acutely ill at the time the study was begun.

A purified diet adequate in calories but devoid of protein (supplying only 0.1 gram of nitrogen daily as determined by macro-Kjeldahl analysis ${ }^{4}$ ) was used in all studies. Its composition and ability to maintain nitrogen balance and constant weight with the addition of 85 grams of purified casein ("Labco") as the sole source of nitrogen have previously been described (13). The diet contained no source of the vitamin B complex except choline in small amounts (30 to $100 \mathrm{mgm}$. daily as estimated from standard food tables). A capsule ${ }^{5}$ containing vitamins $A, C, D, B_{1}, B_{2}$, niacin, $B_{6}$, and pantothenic acid was given daily.

Protein was supplied intravenously as a 10 per cent solution of amino acids ${ }^{6}$ prepared by the recombination

4 One patient (J. G.) received 15 grams of "Nescafe" daily, increasing the nitrogen intake by 0.25 gram.

5 "Dayamin" supplied through the courtesy of the Abbott Laboratories, North Chicago, Illinois.

- Developed and distributed by Merck and Company, Inc., Rahway, New Jersey, who supplied the material used in this investigation. 


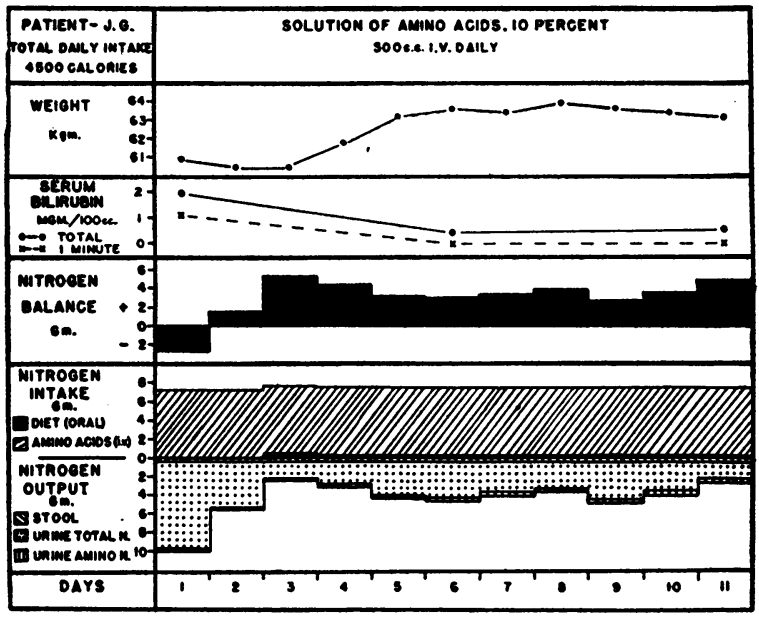

FIG. 1

of fractions of an acid hydrolysate of casein. The prodduct contains no peptides, is essentially devoid of glutamic and aspartic acids, and is supplemented with dl-tryptophane and glycine so that it contains the eight amino acids essential for man (14). The composition of the solution employed (average of the nearly identical lots) and the quantity of amino acids infused are tabulated in Table II. The results are based on analyses by microbiological assay (15).

The basal diet was ingested at regular meal hours. The day's protein ( 500 to $1000 \mathrm{cc}$. of the 10 per cent solution of amino acids) was administered in one rapid intravenous injection each morning, usually over a period of one-half to one and one-half hours. Hypertonic glucose ( 50 to 100 grams) was added to the infusion mixture, and the injection was made one hour after a 1,000 calorie breakfast, in order to achieve maximum utilization of the infused amino acids by the simultaneous provision of adequate carbohydrate and protein (16). The total intake for the four patients during the study averaged 4,500 (J. G.), 1700 (B. B.), 3,500 (W. C.), and 4,200 (J. Q.) calories daily.

The daily urine and pooled stool nitrogen analyses were determined by the standard micro- or macro-Kjeldahl methods. The alpha amino nitrogen was determined by the gasometric ninhydrin method as described by Hamilton and Van Slyke for blood (17), and by Van Slyke, MacFadyen, and Hamilton for urine (18). The serum non-protein nitrogen was determined by Folin's microKjeldahl method with direct nesslerization (19). The urines were assayed for the eight amino acids essential for man and for arginine and histidine by the microbiological method of Stokes et al. (15). As measurements of liver function, the serum bilirubin (20), thymol turbidity (21) and flocculation, urine urobilinogen, plasma prothrombin concentration, bromsulphalein retention, and serum albumin concentration $(22,23)$ were determined. Tissue obtained by punch biopsy ("Vim"-Silverman needle) from the liver of one subject both preceding and following the study period was fixed in 10 per cent formalin, stained with hematoxylin and eosin, and examined microscopically.

\section{RESULTS}

The amino acid mixture was well tolerated clinically. No untoward reactions were noted by patients J. G. and J. Q., even though the infusion of 50 grams of amino acids was usually completed within one hour. A transient diminution of appetite was noted by patient W. C. following several of the infusions, but rarely persisted for more

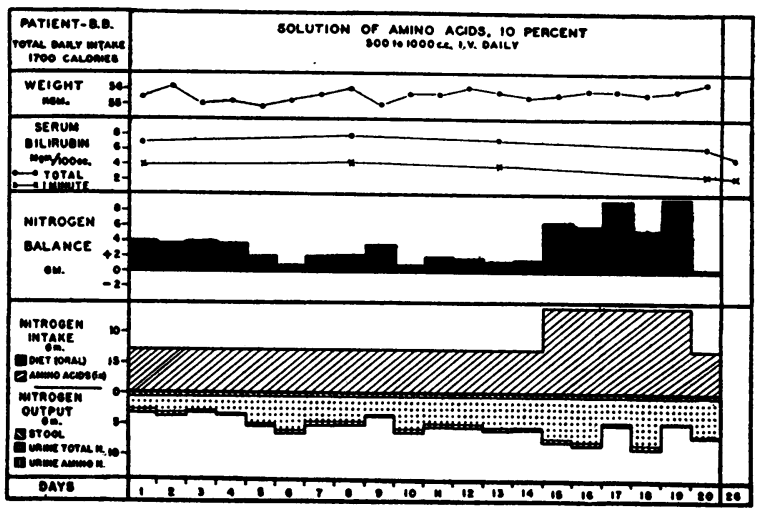

FIG. 2

than one or two hours. Nausea and retching occurred on three occasions following an attempt at forced feeding of sweetened drinks immediately after the infusion. Patient B. B. complained of constant anorexia that both preceded and followed the present study. Although this digestive disturbance was not aggravated further by infusions of $500 \mathrm{cc}$. of the amino acid solution, 1,000 cc. infusions, even though administered more slowly, were followed on three occasions by nausea and vomiting. Thrombosis of the infused vein did not occur in any patient. An increased incidence of untoward reactions was not observed while the patients were deeply jaundiced and acutely ill. Despite the severity of the patients' illness and the rapidity of the infusions, distressing symptoms were noted but six times following 79 infusionsa reaction incidence of less than 8 per cent.

The nitrogen balance data for these patients is summarized in Table III and plotted in Figures 1-4. Patient J. G. maintained a positive nitrogen balance throughout the 11 day study period, except for day one. Although the daily infusion of 
50 grams of amino acids (500 cc. of the 10 per cent solution) to this subject, together with the diet, supplied slightly less than 0.8 gram of protein per kilogram of body weight, an average positive balance of 3.0 grams of nitrogen daily was realized. Patient W. C. received 100 grams of amino acids $(1,000 \mathrm{cc}$. of the 10 per cent solution) intravenously daily for 18 days and retained a total of 50.8 grams of nitrogen, or an average positive balance of 2.8 grams of nitrogen daily. During a 15 day period while patient B. B. received 50 grams of amino acids parenterally daily, the nitrogen balance averaged +2.2 grams daily, and increased to +7.4 grams of nitrogen daily for five days when the quantity of protein administered was doubled. The excretion of nitrogen in the urine increased little despite the large increase in the quantity of amino acids infused. Patient J. $Q$. was in slight positive nitrogen balance only during the final six days of a 30 day study period while receiving 100 grams of amino acids intravenously daily. Nitrogen balance was persistently

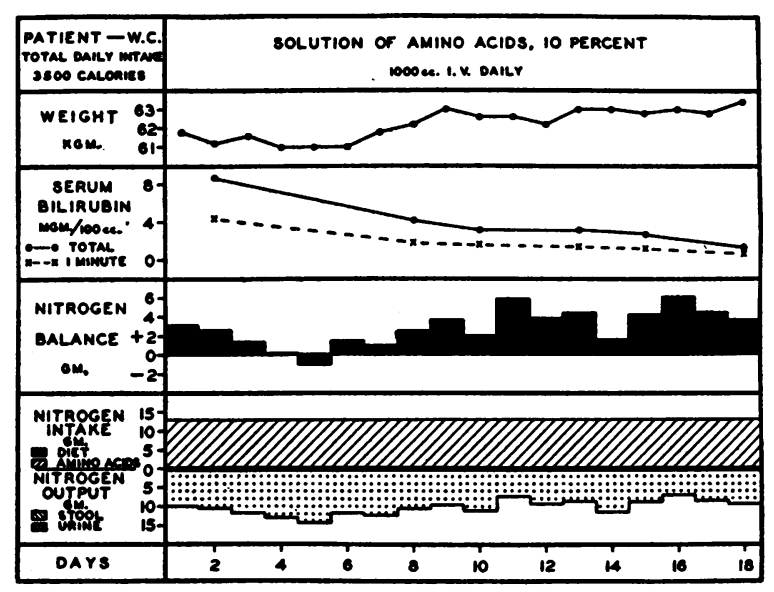

FIG. 3

negative throughout a preceding 22 day period while receiving 50 grams of amino acids intravenously daily and a two day period while receiving 75 grams daily. During the protracted period of negative nitrogen balance, the nitrogen-sparing effects of individual amino acid supplements were investigated. The addition of dl-phenylalanine ( 2 grams) and of dl-threonine ( 3 grams) individually and combined, given by mouth one hour prior to the intravenous infusion, had no apparent effect on the quantity of nitrogen excreted in the urine.
Thus the negative nitrogen balance persisted unaltered until 100 grams of the amino acid mixture was supplied each day.

The serum concentration of alpha amino and of non-protein nitrogen and the urinary excretion of alpha amino nitrogen in each individual did not vary greatly during the study (Table IV). Since the amino acid content of serum is usually 10 to 40 per cent greater than that of plasma (24), the normal range of alpha amino nitrogen in this laboratory of from 2.9 to $4.6 \mathrm{mgm}$. per cent for plasma (9) would be increased to from 3.2 to 6.4 mgm. per cent for serum. Although several of the fasting serum alpha amino nitrogen values obtained in the patient (W. C.) receiving 100 grams of amino acids intravenously daily for 18 days were elevated, the values averaged $5.9 \mathrm{mgm}$. per $100 \mathrm{cc}$. of serum which is within the normal range.

A slight weight gain occurred in each patient (Figures 1-4). Minimal peripheral edema developed in patient J. G. during the first five days of the study coincident with the inadvertent provision of supplemental salts ( 5 grams $\mathrm{NaCl}$ and 1 gram $\mathrm{KCl}$ ), and subsided with their cessation. Although sodium, other than that present in the basal diet, was not supplied the other patients, definite peripheral edema occurred in patient J. Q. and increased in degree as the gain in weight continued, and was associated with a fall in the plasma albumin concentration from 2.6 to 1.8 grams per $100 \mathrm{cc}$. Edema was not discernible in the other patients.

Improvement in liver function tests was observed in all patients during the period of study

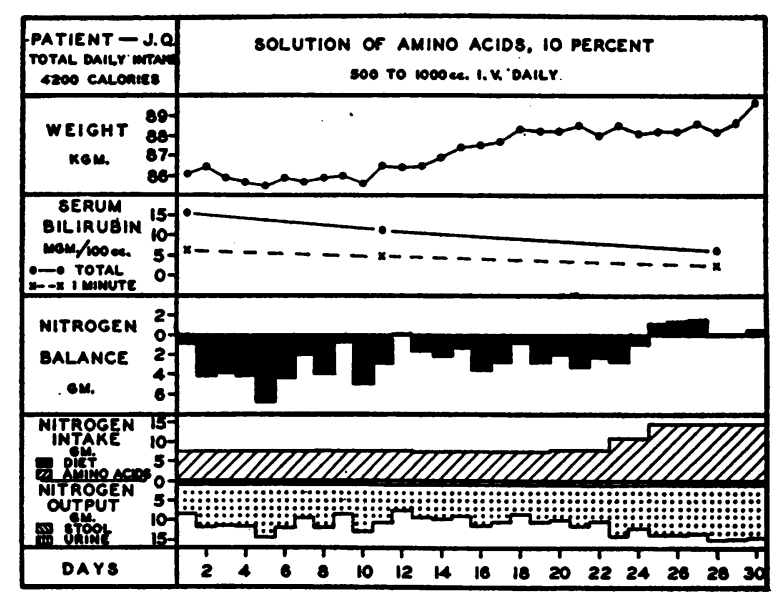

FIG. 4 
TABLE I

Clinical and laboratory observations of patients with cirrhosis of the liver

\begin{tabular}{|c|c|c|c|c|c|c|c|c|c|}
\hline \multirow{2}{*}{\multicolumn{2}{|c|}{$\frac{\begin{array}{c}\text { Patient } \\
\text { (Age, Sex) }\end{array}}{\text { Condition of study }}$}} & \multicolumn{2}{|c|}{ (31. Male) } & \multicolumn{2}{|c|}{$\begin{array}{l}\text { B. B. } \\
\text { (45, Female) }\end{array}$} & \multicolumn{2}{|c|}{$\begin{array}{l}\text { W. C. } \\
\text { (53, Male) }\end{array}$} & \multicolumn{2}{|c|}{ (48, M. Male) } \\
\hline & & $\begin{array}{l}\text { Before } \\
\text { study }\end{array}$ & $\begin{array}{l}\text { After } \\
\text { study }\end{array}$ & $\begin{array}{l}\text { Before } \\
\text { study }\end{array}$ & $\begin{array}{l}\text { After } \\
\text { study }\end{array}$ & $\begin{array}{l}\text { Before } \\
\text { study }\end{array}$ & $\begin{array}{l}\text { After } \\
\text { study }\end{array}$ & $\begin{array}{l}\text { Before } \\
\text { study }\end{array}$ & $\underset{\text { study }}{\text { After }}$ \\
\hline \multicolumn{2}{|l|}{ Jaundice* } & 0 & $\mathbf{0}$ & $3+$ & $2-3+$ & $3+$ & 0 & $4+$ & $2+$ \\
\hline \multicolumn{2}{|l|}{ Spider angiomata* } & $2+$ & $2+$ & $4+$ & $4+$ & 0 & 0 & $2+$ & $2+$ \\
\hline \multicolumn{2}{|l|}{ Liver size $(\mathrm{cm})}$. & 4 & 4 & 16 & 16 & 2 & 0 & 11 & 7 \\
\hline \multicolumn{2}{|l|}{ Spleen size $(\mathrm{cm})}$. & 0 & 0 & 2 & $\mathbf{0}$ & 0 & 0 & 3 & 1 \\
\hline \multicolumn{2}{|l|}{ Ascites* } & 0 & 0 & $2-3+$ & $2+$ & \pm & 0 & $1+$ & $1+$ \\
\hline \multicolumn{2}{|l|}{ Peripheral edema* } & 0 & $1+$ & 0 & 0 & 0 & 0 & 0 & $1+$ \\
\hline \multirow{2}{*}{ 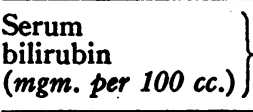 } & $1 \mathrm{~min}$. & 1.1 & 0.1 & 3.8 & 2.6 & 4.5 & 0.8 & 6.6 & 2.6 \\
\hline & Total & 1.9 & 0.7 & 7.3 & 6.4 & 8.7 & 1.2 & 15.5 & 6.6 \\
\hline \multicolumn{2}{|l|}{$\begin{array}{l}\text { Thymol turbidity } t \\
\left.\text { (cc. } \mathrm{BaSO}_{4}\right)\end{array}$} & 0.7 & 0.6 & 2.8 & 2.4 & 3.9 & 2.7 & 4.5 & 3.2 \\
\hline \multicolumn{2}{|c|}{ Thymol flocculation* } & 0 & 0 & $3+$ & $1+$ & $3+$ & $1+$ & $1+$ & $1+$ \\
\hline \multicolumn{2}{|l|}{ Urine bile* } & $\mathbf{0}$ & 0 & $2+$ & $1-2+$ & $3+$ & $\mathbf{0}$ & $4+$ & $2+$ \\
\hline \multicolumn{2}{|l|}{ Urine urobilinogen } & & & $1: 256$ & & $1: 256$ & & $1: 80$ & \\
\hline \multicolumn{2}{|c|}{$\begin{array}{l}\text { Prothrombin time } \\
\text { (per cent of normal) }\end{array}$} & 73 & & 43 & & 60 & & 35 & \\
\hline \multirow{2}{*}{$\left.\begin{array}{l}\text { Serum } \\
\text { proteins } \\
(\text { grams per } 100 c c .)\end{array}\right\}$} & Total & & 6.5 & 6.0 & 5.8 & 5.8 & 5.7 & 6.7 & 5.2 \\
\hline & Albumin & & 4.1 & 2.1 & 2.4 & 3.1 & 2.2 & 2.6 & 1.8 \\
\hline \multicolumn{2}{|c|}{$\begin{array}{l}\text { Bromsulphalein retention } \\
\text { (per cent) } \ddagger\end{array}$} & & 14 & & & & 20 & & \\
\hline
\end{tabular}

* 0 to $4+$

† Normal range: Below $1.7 \mathrm{cc}$. BaSO,

$\ddagger$ At 45 minutes after intravenous injection of $5 \mathrm{mgm}$. dye per kilogram of body weight.

(Table I, Figures 1-4). A progressive decline in the serum bilirubin, degree of jaundice, and urine bile was the most marked change noted. The thymol turbidity and thymol flocculation tests were found abnormal in three patients before the study, and in each instance showed slight change toward normal. In three instances where the serum protein concentrations were determined before and after the study period, the total protein remained relatively constant, while the albumin rose slightly in one and fell in the others. By physical examination, in addition to a lessening of jaundice, it was noted that the liver size decreased in two patients, and remained unchanged in the others. The spleen became less readily palpable in the two patients with splenomegaly. The degree of ascites, when present, was not appreciably altered.
As mentioned previously, peripheral edema became evident in two patients. In addition to generally improved liver function tests and physical findings, each patient experienced subjective improvement. This was evidenced by increased physical and mental activity, a greater desire to eat, and an enhanced sense of well-being.

Liver punch biopsies obtained from patient $W$. C. prior to the study and at its conclusion (20 day interval) were reported as follows: ${ }^{7}$

An adequate portion of liver was obtained. The

7 The authors gratefully acknowledge the assistance of Norman Zamcheck, M.D., in the pathological interpretation of these specimens. It is regretted that liver biopsy was contraindicated in patients B. B. and J. $Q$. because of a prolonged prothrombin time (not responding to vitamin $\mathrm{K}$ therapy) and deep jaundice. 
TABLE II

Composition of the 10 per cent solution of amino acids

$\begin{array}{lc} & \begin{array}{c}\text { Amounts of } \\ \text { amino acids } \\ \text { in } 500 \text { cc. } \\ \text { of the 10 } \\ \text { per cent } \\ \text { solution* } \\ \text { grams }\end{array} \\ \text { Arginine } & 1.3 \\ \text { Histidine } & 2.0 \\ \text { Isoleucine } & 4.2 \\ \text { Leucine } & 8.4 \\ \text { Lysine } & 5.2 \\ \text { Methionine } & 2.0 \\ \text { Phenylalanine } & 2.1 \\ \text { Threonine } & 0.9 \\ \text { Tryptophane } & 0.45 \\ \text { Valine } & 3.5\end{array}$

* Determinations by microbiological assay (1-form) (15). Also contains: 0.45 gram d-tryptophane, $0.1-0.3$ gram glutamic acid, 0.1 gram tyrosine, 11.3 grams glycine, less than 0.03 gram aspartic acid, and (by difference) 3.5 grams non-assayed amino acids per $500 \mathrm{cc}$. of the 10 per cent solution. Total 10 "essential" amino acids comprise 64 per cent of total amino acids in mixture. Each $500 \mathrm{cc}$ infusion (by analysis) supplies 44 grams of amino acids, 7.0 grams of total nitrogen, and 6.0 grams of alpha amino nitrogen.

appearance was consistent with portal cirrhosis. Marked fibrosis of the portal areas was noted throughout. A moderate number of lymphocytes and a few eosinophiles were scattered through the fibrous tissue. Bile duct proliferation was prominent. A small amount of fat was scattered in focal areas through the liver parenchyma and the liver cells contained only minimal amounts of glycogen. "Alcoholic hyaline" was found. Many bile thrombi were seen obstructing and distending the bile canaliculi.

The second biopsy obtained 20 days later showed distinct improvement in the histologic appearance of the liver structure as follows:

Most notable was a marked increase in cell content of glycogen which distended the liver cells so that they appeared to be increased in size and obscured adjoining sinusoids in many areas. There was a decrease in fat although this had not completely disappeared. No bile thrombi were seen. A few cells contained a small amount of green staining pigment and more green pigment was collected in scattered Küpffer cells. Less striking changes consisted of an apparent decrease both in amount of fibrous tissue and of cellular infiltrate of the portal areas.

The loss in the urine of alpha amino nitrogen and of each of the 10 "essential" amino acids following the infusion of the amino acid solution is tabulated in Table V. ${ }^{8}$ There was a loss from ex-

$8 \mathrm{~A}$ portion of the amino acids excreted into the urine is of endogenous source (25). All values listed in Table $\mathrm{V}$ are in excess of the amount of alpha amino nitrogen or of individual amino acids excreted by patient W. C. the second day while receiving a 3,500 calorie, protein-free diet prior to the present study. These "endogenous" values were: arginine 8.3 ; histidine 71.0 ; isoleucine 5.3 ; leucine 12.6 ; lysine 17.4 ; methionine 4.1 ; phenylalanine 14.8 ; threonine 19.1 ; tryptophane 6.9 ; valine 7.6 ; and alpha amino nitrogen $113 \mathrm{mgm}$. per 24 hours. Although it would have been desirable to obtain "endogenous" amino acid excretion values for each patient, it was not deemed advisable to withhold protein from their diets, particularly since the values for patient W. C. agreed quite closely with those found in the normal (25). Actually, the "endogenous" values are so small in relation to the quantity of amino acids lost following. infusions of protein hydrolysates as to be relatively insignificant.

TABLE III

Nitrogen balance data of four patients with cirrhosis of the liver given 500 to $1,000 \mathrm{cc}$ of a 10 per cent solution of amino acids intravenously daily

\begin{tabular}{|c|c|c|c|c|c|c|c|}
\hline Patient & J. G. & \multicolumn{2}{|c|}{ B. B. } & & \multicolumn{3}{|c|}{ J. Q. } \\
\hline Duration of study & 11 days & 15 days & 5 days & 18 days & 22 days & 2 days & 6 days \\
\hline Amounts given daily & 50 grams & 50 grams & 100 grams & 100 grams & 50 grams & 75 grams & 100 grams \\
\hline $\left.\begin{array}{c}\text { Nitrogen } \\
\text { intake } \\
\text { grams }\end{array}\right\} \begin{array}{l}\text { Intravenous } \\
\text { Diet } \\
\text { Total }\end{array}$ & $\begin{array}{r}78.3 \\
4.0 \\
82.3\end{array}$ & $\begin{array}{r}106.8 \\
0.8 \\
107.6\end{array}$ & $\begin{array}{r}71.0 \\
0.3 \\
71.3\end{array}$ & $\begin{array}{r}234.9 \\
1.6 \\
236.5\end{array}$ & $\begin{array}{r}166.5 \\
2.3 \\
168.8\end{array}$ & $\begin{array}{r}22.1 \\
0.2 \\
22.3\end{array}$ & $\begin{array}{r}88.2 \\
0.6 \\
88.8\end{array}$ \\
\hline $\left.\begin{array}{c}\text { Nitrogen } \\
\text { output } \\
\text { grams }\end{array}\right\} \begin{array}{c}\text { Urine } \\
\text { Stool } \\
\text { Total }\end{array}$ & $\begin{array}{r}44.6 \\
4.4 \\
49.0\end{array}$ & $\begin{array}{r}67.0 \\
7.5 \\
74.5\end{array}$ & $\begin{array}{r}31.9 \\
2.5 \\
34.4\end{array}$ & $\begin{array}{r}180.1 \\
5.6 \\
185.7\end{array}$ & $\begin{array}{r}208.2 \\
22.4 \\
230.6\end{array}$ & $\begin{array}{r}24.0 \\
2.0 \\
26.0\end{array}$ & $\begin{array}{r}78.2 \\
6.1 \\
84.3\end{array}$ \\
\hline $\left.\begin{array}{c}\text { Nitrogen } \\
\text { balance }\end{array}\right\} \begin{array}{l}\text { Total } \\
\text { Av./day }\end{array}$ & $\begin{array}{r}+33.3 \\
+3.0\end{array}$ & $\begin{array}{r}+33.1 \\
+2.2\end{array}$ & $\begin{array}{r}+36.9 \\
+7.4\end{array}$ & $\begin{array}{r}+50.8 \\
+2.8\end{array}$ & $\begin{array}{r}-61.8 \\
-2.8\end{array}$ & $\begin{array}{l}-3.7 \\
-1.9\end{array}$ & $\begin{array}{l}+4.5 \\
+0.8\end{array}$ \\
\hline
\end{tabular}


TABLE IV

Serum concentration of alpha amino and of non-protein nitrogen and urinary excretion of alpha amino nitrogen before, during, and after the administration of 50 to 100 grams of amino acids intravenously daily for from two to four weeks to four patients with cirrhosis of the liver

\begin{tabular}{|c|c|c|c|c|c|}
\hline \multicolumn{2}{|c|}{ Patient } & J. G. & B. B. & w. c. & J. Q. \\
\hline $\left.\begin{array}{c}\text { Serum non-protein } \\
\text { nitrogen } \\
m g m . / 100 c c .\end{array}\right\}$ & $\begin{array}{l}\text { Control } \\
\text { During study } \\
\text { End }\end{array}$ & & $\begin{array}{l}21.6 \\
26.0 \\
32.3\end{array}$ & $\begin{array}{c}25.0 \\
20.2,28.0,24.8, \cdot 20.0 \\
26.8\end{array}$ & $\begin{array}{c}21.1 \\
14.8,17.0 \\
17.2\end{array}$ \\
\hline $\left.\begin{array}{c}\text { Serum alpha amino } \\
\text { nitrogen } \\
m g m . / 100 c c .\end{array}\right\}$ & $\begin{array}{l}\text { Control } \\
\text { During study } \\
\text { End }\end{array}$ & & & $\left\{\begin{array}{c}4.9 \\
7.7,5.0,6.7,8.8 \\
3.8,4.5,6.7,4.4 \\
3.8\end{array}\right.$ & \\
\hline $\left.\begin{array}{c}\text { Urine alpha amino } \\
\text { nitrogen } \\
m g m . / 24 \text { hours }\end{array}\right\}$ & $\begin{array}{l}\text { First third of study } \\
\text { Middle third of study } \\
\text { Final third of study }\end{array}$ & $\begin{array}{l}187 \\
269 \\
390\end{array}$ & $\begin{array}{l}413 \\
505 \\
466\end{array}$ & $\begin{array}{l}2110 \\
1995 \\
1096\end{array}$ & \\
\hline
\end{tabular}

cretion into the urine of from 2.8 to 23.3 per cent of the alpha amino nitrogen administered to the four patients with cirrhosis of the liver. Following daily infusions of 50 grams of the amino acid mixture to patient J. G., and of 50 and 100 grams to patient B. B., only $2.8,5.7$, and 3.7 per cent, respectively, of the administered alpha amino nitrogen was excreted into the urine. The excretion loss was considerably greater, however, following infusions of 100 grams of amino acids daily to patients W. C. and J. Q., and averaged 14.2 and
20.1 per cent, respectively, of the amount given. During the period of persistent negative nitrogen balance while receiving 50 and 75 grams of amino acids daily, patient J. Q. excreted 23.3 and 17.1 per cent, respectively, of the intravenously administered alpha amino nitrogen. In none of the patients did the urinary excretion loss of alpha amino nitrogen correlate with the rate at which the infusion was administered.

There was a considerable variation among patients in the quantity of individual amino acids, as

TABLE V

10 "essential" amino acids and alpha amino nitrogen excreted in the urine in the 24 hours after administration of 500 to 1,000 cc. of the 10 per cent solution of amino acids to four patients with cirrhosis of the liver

\begin{tabular}{|c|c|c|c|c|c|c|c|c|c|c|}
\hline Patient & \multirow{2}{*}{\multicolumn{2}{|c|}{$\frac{\text { J. } G .}{11 \text { days }}$}} & \multirow{2}{*}{\multicolumn{2}{|c|}{$\begin{array}{c}\text { B.B.8 } \\
15 \text { days }\end{array}$}} & \multirow{2}{*}{\multicolumn{2}{|c|}{$\begin{array}{c}\text { W. C. } \\
18 \text { days }\end{array}$}} & \multicolumn{4}{|c|}{ J. Q.II } \\
\hline Duration of study & & & & & & & & & & ays \\
\hline Amounts given daily & \multicolumn{2}{|c|}{50 grams } & \multicolumn{2}{|c|}{50 grams } & \multicolumn{2}{|c|}{100 grams } & \multicolumn{2}{|c|}{100 grams } & \multicolumn{2}{|c|}{50 grams } \\
\hline $\begin{array}{l}\text { Arginine } \\
\text { Histidine } \\
\text { Isoleucine } \\
\text { Leucine } \\
\text { Lysine } \\
\text { Methionine } \\
\text { Phenylalanine } \\
\text { Threonine } \\
\text { Tryptophane } \\
\text { Valine } \\
\text { Alpha amino nitrogen }\end{array}$ & $\begin{array}{c}m g m . * \\
2.0 \\
80.0 \\
21.5 \\
34.3 \\
124 \\
19.4 \\
15.4 \\
38.9 \\
8.6 \\
29.0 \\
169\end{array}$ & $\begin{array}{l}\text { per cent } \\
0.2 \\
3.6 \\
0.5 \\
0.4 \\
2.5 \\
1.0 \\
0.7 \\
3.9 \\
1.9 \\
0.8 \\
2.8\end{array}$ & $\begin{array}{c}m g m . * \\
8.1 \\
154 \\
45.6 \\
115 \\
162 \\
41.4 \\
52.6 \\
75.5 \\
20.3 \\
97.4 \\
348\end{array}$ & $\begin{array}{l}\text { per cent } \dagger \\
0.6 \\
6.8 \\
1.0 \\
1.3 \\
3.3 \\
2.1 \\
2.5 \\
7.6 \\
4.5 \\
2.7 \\
5.7\end{array}$ & $\begin{array}{c}m g m . * \\
42.1 \\
481 \\
700 \\
1432 \\
1113 \\
479 \\
550 \\
490 \\
129 \\
1018 \\
1621\end{array}$ & $\begin{array}{c}\text { per cent† } \\
1.9 \\
20.0 \\
9.7 \\
9.6 \\
11.1 \\
11.7 \\
14.1 \\
37.7 \\
14.3 \\
15.7 \\
14.2\end{array}$ & $\begin{array}{c}m g m . * \\
41.3 \\
1504 \\
972 \\
2668 \\
1675 \\
1238 \\
931 \\
760 \\
260 \\
1312 \\
2429\end{array}$ & $\begin{array}{c}\text { per cent } \dagger \\
1.6 \\
36.6 \\
12.3 \\
16.3 \\
14.7 \\
32.6 \\
23.3 \\
40.0 \\
28.9 \\
19.3 \\
20.1\end{array}$ & $\begin{array}{l}m g m \cdot * \\
20.2 \\
823 \\
293 \\
732 \\
579 \\
456 \\
335 \\
660 \\
156 \\
393 \\
1410\end{array}$ & $\begin{array}{c}\text { per cent } \dagger \\
1.6 \\
40.2 \\
7.4 \\
9.0 \\
10.1 \\
24.0 \\
13.6 \ddagger \\
45.8 \ddagger \\
34.7 \\
11.6 \\
23.3\end{array}$ \\
\hline
\end{tabular}

* Mgm. of amino acid or of alpha amino nitrogen in excess of that excreted on a 3,500 calorie, protein-free diet. ${ }^{8}$ $\dagger$ Per cent of administered amino acid or of administered alpha amino nitrogen excreted in urine. Calculated from the actual composition of each lot used, which differed slightly from the averaged values in Table II.

$\ddagger$ Values corrected for the supplemental phenylalanine and threonine given during part of this period.

8 Patient B. B. excreted an average of $450 \mathrm{mgm}$. of alpha amino nitrogen daily for a five day period while receiving 100 grams of amino acids intravenously daily, or 3.7 per cent of the quantity infused.

II Patient J. Q. excreted an average of $1552 \mathrm{mgm}$. of alpha amino nitrogen daily for a two day period while receiving 75 grams of amino acids intravenously daily, or 17.1 per cent of the quantity infused. 
well as of alpha amino nitrogen, excreted into the urine (Table V). However, it is apparent that certain of the amino acids were more freely lost than were others. Thus, as a group, the patients excreted fairly large percentages of administered threonine and histidine, a small percentage of arginine, and intermediate percentages of the other amino acids. The percentage of individual amino acids and of alpha amino nitrogen given which was lost in the urine by patient J. Q. was as great when 50 grams were given daily and negative nitrogen balance resulted, as when he received twice the quantity and nitrogen equilibrium was attained.

The patterns of the 10 "essential" amino acids in the solution administered intravenously and in the urine are shown in Table VI and plotted in Figure 5. The proportion of the "essential" amino acids in the mixture differed considerably from that excreted in the urine. For example, although arginine and histidine were present in similar proportions in the mixture infused (4.2 and 6.6 per cent of the total 10 "essential" amino acids, respectively), their pattern in the urine was altered so that proportionately far more of the 10 amino acids excreted (average of the four patients) was composed of histidine (15.6 per cent) than of arginine ( 0.7 per cent). The amino acid pattern

\section{TABLE VI}

Comparison of the patterns of the 10 "essential" amino acids administered and excreted following amino acid infusions to patients with liver disease and normal subjects

\begin{tabular}{|c|c|c|c|c|c|c|c|}
\hline & \multicolumn{7}{|c|}{ Per cent of total of 10 "essential" amino acids } \\
\hline & \multirow{2}{*}{ Given* } & \multicolumn{5}{|c|}{ Excreted in liver disease $\dagger$} & \multirow{2}{*}{$\begin{array}{l}\text { Excreted } \\
\text { in nor- } \\
\text { mals }\end{array}$} \\
\hline & & J. G. & B. B. & W. C & .J. Q. & $\begin{array}{c}\text { Aver- } \\
\text { age }\end{array}$ & \\
\hline $\begin{array}{l}\text { Arginine } \\
\text { Histidine } \\
\text { Isoleucine } \\
\text { Leucine } \\
\text { Lysine } \\
\text { Methionine } \\
\text { Phenylalanine } \\
\text { Threonine } \\
\text { Tryptophane } \\
\text { Valine }\end{array}$ & $\begin{array}{r}4.2 \\
6.6 \\
14.1 \\
28.1 \\
17.3 \\
6.7 \\
6.9 \\
3.0 \\
1.5 \\
11.6\end{array}$ & \begin{tabular}{|r|}
0.5 \\
21.5 \\
5.8 \\
9.2 \\
33.2 \\
5.2 \\
4.1 \\
10.4 \\
2.3 \\
7.8
\end{tabular} & $\begin{array}{r}1.0 \\
20.0 \\
5.9 \\
14.9 \\
21.0 \\
5.4 \\
6.8 \\
9.8 \\
2.6 \\
12.6\end{array}$ & $\begin{array}{r}0.7 \\
7.5 \\
10.9 \\
22.3 \\
17.3 \\
7.4 \\
8.5 \\
7.6 \\
2.0 \\
15.8\end{array}$ & \begin{tabular}{|r|}
0.4 \\
13.2 \\
8.6 \\
23.5 \\
14.7 \\
10.9 \\
8.2 \\
6.7 \\
2.3 \\
11.5
\end{tabular} & $\begin{array}{r}0.7 \\
15.6 \\
7.8 \\
17.5 \\
21.5 \\
7.2 \\
6.9 \\
8.6 \\
2.3 \\
11.9\end{array}$ & $\begin{array}{r}1.8 \\
16.1 \\
4.7 \\
14.0 \\
20.6 \\
8.1 \\
9.2 \\
13.8 \\
2.2 \\
9.5\end{array}$ \\
\hline
\end{tabular}

* Calculated from the quantity of amino acids given, Table II.

† Calculated from the quantity of amino acids excreted, Table V. Excretion pattern of patient J. Q. calculated from 100 grams period.

$¥$ Average value of eight infusions in normal subjects given $500 \mathrm{cc}$. of the 10 per cent solution of amino acids intravenously (35).

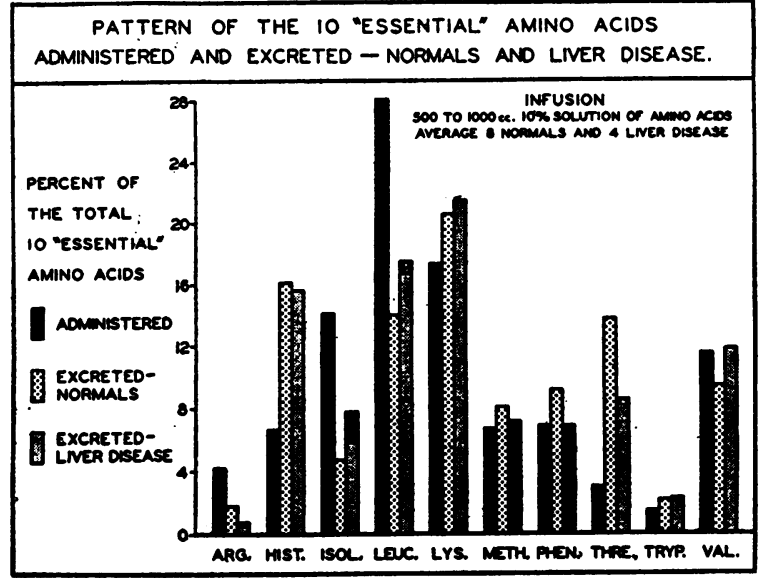

FIG. 5

in the urine following the larger (100 gram) infusions in patients W. C. and J. Q. more closely resembled the pattern of the solution given than that following the 50 gram infusions in patients J. G. and B. B.

\section{DISCUSSION}

Patients with cirrhosis of the liver can maintain a positive nitrogen balance if adequate dietary protein is given $(26,27)$. When an adequate dietary intake of protein can not be maintained, it would appear desirable to provide the protein in a hydrolyzed form intravenously. None of the objections raised to the administration of protein hydrolysates intravenously to patients with liver disease has gone unchallenged, and the present paper suggests that they were unfounded. ${ }^{\circ}$

\section{Clinical tolerance of parenterally administered amino acids in liver disease}

For several years in this clinic protein hydrolysates have been administered intravenously as a therapeutic adjunct in the treatment of patients with liver disease. The protein hydrolysates employed (both acid and enzymatically hydrolyzed) were as well tolerated clinically by patients with hepatitis (infectious, toxic, homologous serum),

9 Because of improved methods of manufacturing protein hydrolysates, many of the untoward reactions of a decade ago are rarely encountered today. Impressions and conclusions made when less refined products were employed in the past should not necessarily continue to serve as criteria of the value (or lack of value) of hydrolysates now used. 
cirrhosis of the liver (Laennec's, biliary, toxic, pigment), Wilson's disease, liver coma, and obstructive jaundice, as they were by patients with other illnesses or by normal individuals. The relative freedom from untoward reactions following the rapid and repeated daily infusions for from two to four weeks of from $500 \mathrm{cc}$. to $1,000 \mathrm{cc}$. of the 10 per cent solution of amino acids to the four patients with severe liver disease observed in the present study confirms the previous impression that amino acids may be administered intravenously with relative impunity to patients with liver disease. The reaction incidence (nausea) of less than 8 per cent noted in the patients with liver disease was similar to that observed in a larger series of individuals following infusions of the same hydrolysate (28).

\section{Metabolism of parenterally administered amino acids in liver disease}

Evidence that the intravenously administered amino acids were normally metabolized by the patients with liver disease was the positive nitrogen balance attained. Thus, three of the patients ( $\mathrm{J}$. G., B. B., and W. C.) maintained a positive nitrogen balance with an average retention of 3 grams of nitrogen daily throughout the period of study. The nitrogen balance in one of these patients increased from +2.2 grams daily to +7.4 grams daily when the quantity of protein administered was doubled. The fourth patient (J. Q.) was in slight positive nitrogen balance while receiving 100 grams of amino acids daily for six days. The latter individual, however, failed to maintain nitrogen equilibrium while receiving 50 and 75 grams of amino acids intravenously daily for 22 and for two days, respectively. Oral supplements of phenylalanine and threonine, amino acids which favor nitrogen conservation in dogs (29), did not alter the negative nitrogen balance. The provision of $\mathbf{5 0}$ grams of amino acids to this patient of large stature only represented approximately 0.5 gram of protein per kilogram of body weight which borders on the minimum oral requirement (30). Furthermore, the quantitative requirement of hydrolyzed protein administered intravenously is likely greater than that of an equivalent quantity of whole or of hydrolyzed protein given orally $(31,32)$. Because the latter patient maintained nitrogen equilibrium while receiving 100 grams of amino acids intravenously daily, it is suggested that during the protracted period of negative nitrogen balance he received an insufficient quantity of amino acids to fulfill the body protein requirements, particularly in view of the adequate caloric intake maintained throughout the study $(4,200$ calories daily). Thus, the provision of adequate quantities of amino acids intravenously permitted each of the patients with cirrhosis of the liver to achieve a positive nitrogen balance. The positive nitrogen balance did not reflect a retention of nitrogenous products in the blood, for the serum nonprotein nitrogen remained constant throughout the study (Table IV).

Further evidence that the infused amino acids were completely metabolized was the failure to observe a progressive rise in the serum alpha amino nitrogen concentration in the patient receiving 100 grams of amino acids intravenously daily for 18 days (W. C., Table IV). Although the ability of an impaired liver to deaminize promptly intravenously administered amino acids has been questioned, the blood amino acid values following infusions of protein hydrolysates do not differ greatly in normals and in patients with liver disease, as shown in Figure 6. Thus, patients with liver disease are able to metabolize intravenously injected amino acids promptly and completely, whether given once as in the "tolerance tests" reported in the literature $(2,7-9)$ and plotted in Figure 6 , or given repeatedly as in the present study.

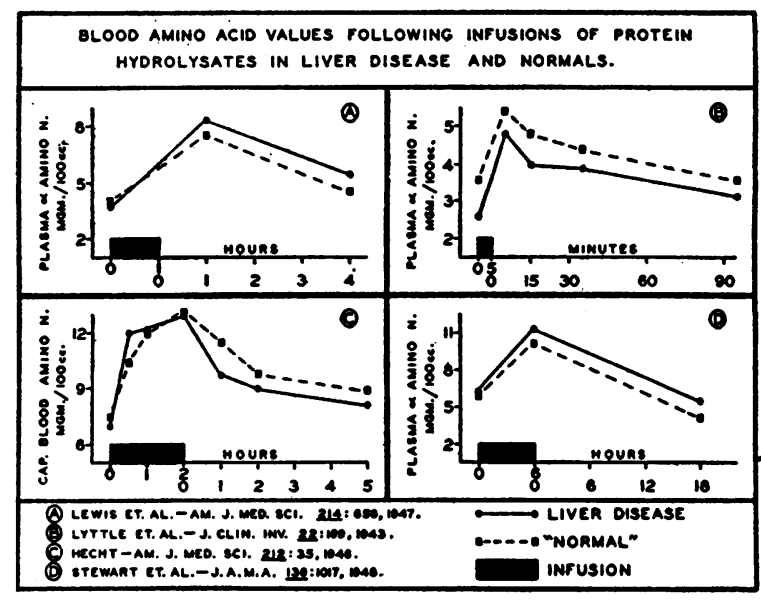

FIG. 6 
The significance of the slight weight gain observed in each of the patients (Figures 1-4) is difficult to evaluate. Gain in weight was associated entirely in one patient (J. Q.) and, at least in part, in a second (J. G.) with fluid retention, since both developed minimal peripheral edema during the study. Since patients with "decompensated" cirrhosis of the liver have an avidity for sodium and water (33), it can not be stated with certainty that fluid retention did not occur in all of the patients in this study.

\section{Excretion of parenterally administered amino acids in liver disease}

It was reported previously from this clinic that the average daily excretion of alpha amino nitrogen and of the 10 "essential" amino acids in the urine of patients with severe liver disease eating ad libitum did not differ markedly from normal subjects, although there was considerable variation among patients in the quantity of individual amino acids excreted (34). Similarly, the "endogenous" excretion of amino acids by patient W. C. ${ }^{8}$ was similar to that found in the normal (25). The present study presents further evidence that parenterally administered amino acids are excreted in patients with severe liver disease in a manner differing little from normal. The loss of alpha amino nitrogen in the urine by the patients with liver disease (Table V) was similar to that observed in a previous study in normals following infusions of equivalent quantities of the same hydrolysate (35). Thus, there was an average urinary loss following $500 \mathrm{cc}$. infusions of 9 per cent (range 3 to 13 per cent) of the amino nitrogen administered to normal subjects and of 3 and 6 per cent to patients with liver disease (J. G. and B. B.). The urinary loss of amino nitrogen following 100 gram amino acid infusions averaged 14 per cent (range 9 to 19 per cent) in normals and 4, 14 , and 20 per cent in patients with liver disease (B. B., W. C., and J. Q.). Furthermore, as in the normal individuals, the urinary excretion loss of alpha amino nitrogen of the patients with liver disease correlated more closely with the size of the infusion than with the speed at which it was given. A progressive increase in the urinary excretion of alpha amino nitrogen did not occur in any patient during the study (Table IV).
The observation that patients with severe liver disease excreted fairly large percentages of administered threonine and histidine and smaller percentages of the other amino acids following infusions of the amino acid solution is further evidence that amino acid excretion in liver disease is normal, since these amino acids were similarly excreted following amino acid infusions in normal subjects (35). Furthermore, the post-infusion pattern of the "essential" amino acids excreted in the urine of the patients with cirrhosis was similar to that in normals, although the individual amino acids were not excreted in the same proportion as administered in either group (Table VI, Figure 5). The excretion pattern following the larger (100 gram) infusions in the patients with liver disease more closely resembled the pattern of the solution given than that following the $\mathbf{5 0}$ gram infusions. It was previously observed in normals that the amino acid pattern following rapid infusions of the amino acid solution more closely resembled the pattern of the amino acids given than that following infusions given more slowly (35). Thus, the administration of amino acids intravenously slowly and in small quantity is followed by excretion in the urine of but minimal amounts of amino acids in a pattern differing from the pattern of the amino acids given, while the infusion of amino acids rapidly and in large amounts results in a greater excretion loss of alpha amino nitrogen and of individual amino acids in a proportion quite similar to that in the solution administered. As discussed previously (35), an interpretation of these observations is not possible until further data relating to renal clearance studies in man are available. Nevertheless, the similarity in the renal excretion of amino acids by normals and by patients with liver disease is apparent.

\section{Therapeutic value of parenterally adminis- tered amino acids in liver disease}

Improvement in the liver disease was observed in all patients during the period of study, as evidenced by a progressive decline in the serum bilirubin, degree of jaundice, and urine bile in each patient, a decrease in the size of the liver and spleen in two patients, and a distinct improvement in the histologic appearance of the liver structure in the second biopsy obtained in one patient. The im- 
provement in the liver function tests and physical findings was as marked when insufficient amino acids were administered intravenously and negative nitrogen balance resulted (patient J. Q., Table $I$ and Figure 4), as when sufficient amino acids were available to attain positive nitrogen balance. This finding suggests that improvement in liver function in man can proceed even in the face of a negative nitrogen balance, perhaps as a result of mobilization of tissue proteins. That repair of injured tissue can take place during periods of insufficient dietary protein intake and negative nitrogen balance by the diversion of nitrogen from one organ of the body to another finds support in several studies. Thus, some replacement of liver protein occurs in partially hepatectomized rats maintained on a protein-free diet (36), blood regeneration proceeds satisfactorily in anemic animals and man during periods of negative nitrogen balance $(37,38)$, and considerable tissue repair (fibroplasia) occurs in the experimental wounds of rats maintained on a low protein diet (39) and presumably also during the "catabolic period" after damage in man. Under these circumstances, however, an adequate protein intake and retention would be necessary in order to replace the depleted tissue protein, and perhaps to enhance repair of the injured tissue.

Further studies in man are needed to determine whether liver repair is more satisfactorily achieved by an adequate rather than by an inadequate protein intake, or by diets containing supplements of additional protein or of "lipotropic" substances. The present study does demonstrate, however, that liver repair in man can proceed when amino acids, even in amounts insufficient for nitrogen equilibrium, are administered intravenously as the sole source of nitrogen and of lipotropic substances except for small amounts of choline.

Post and Patek observed that patients with cirrhosis of the liver absorb and retain food protein as do patients with simple protein starvation, and differ from the latter group only by an impaired ability to synthesize serum albumin (27). The difficulty of increasing the serum albumin concentration in undernourished patients with chronic liver cirrhosis by feeding a nutritious diet high in protein is well established $(40,41)$. Thus, it is not surprising that the serum concentration of total protein and of albumin did not rise in the patients during the present study (Table I).

It should be emphasized that the present study was undertaken to determine the clinical tolerance, metabolism and excretion, and therapeutic value of amino acids administered intravenously to patients with liver disease. It is neither the authors' intent nor desire to suggest that patients with liver disease receive each day a synthetic protein-free diet by mouth, and 50 to 100 grams of amino acids by vein as the sole source of nitrogen and of lipotropic substances. We firmly believe that therapy in liver disease is based upon the fundamental principle of insuring that nutritious food is eaten, digested, and absorbed. When an adequate intake of nutritious foods can not be maintained, however, the results of the present study indicate the desirability of providing the protein nutrients intravenously as amino acids.

\section{SUMMARY}

1. Four patients with active cirrhosis of the liver were given a protein hydrolysate intravenously daily for from two to four weeks as the sole source of nitrogen. A purified diet furnished adequate calories, but only small amounts of choline.

2. The amino acid solution ( 50 to 100 grams of amino acids) was administered in one rapid injection each morning and was well tolerated clinically.

3. The provision of adequate quantities of amino acids intravenously permitted each of the patients to achieve a positive nitrogen balance which was not associated with azotemia or hyperaminoacidemia.

4. There was a Toss into the urine of from 3 to 23 per cent of the alpha amino nitrogen administered. This loss correlated more closely with the size of the infusion than with the speed at which it was given, and did not progressively increase in any patient during the study. The individual amino acids were not excreted in the urine in the same proportion as administered, so that as a group the patients excreted fairly large percentages of administered threonine and histidine, a small percentage of arginine, and intermediate percentages of the other amino acids. These data are similar to those observed in normals. 
5. Improvement in the liver disease was observed in all the patients during the period of study, as evidenced by a progressive decline in the serum bilirubin, degree of jaundice, and urine bile in each patient, a decrease in the size of the liver and spleen in two patients, and a distinct improvement in the histologic appearance of the liver structure in one patient.

6. Improvement in liver function tests and physical findings was even observed in one patient who received insufficient amino acids and was in negative nitrogen balance for three weeks. This finding suggests that improvement in liver function in man can proceed even in the face of a negative nitrogen balance, perhaps as a result of mobilization of tissue proteins.

7. It is concluded that intravenously administered amino acids were well tolerated by these patients with severe liver disease, were metabolized and excreted in a manner differing little from normal, and permitted clinical improvement although administered as the sole source of nitrogen and of lipotropic substances.

\section{ACKNOWLEDGMENTS}

The authors wish to thank the Misses Alice Ballou, Ellen Cobino, Ellen Doyle, Elaine Hirshberg, and Catherine Murphy for their technical assistance, and Miss Kathleen Clinton for preparing and calculating the diets used.

\section{BIBLIOGRAPHY}

1. Patek, A. J., Jr., and Post, J., Treatment of cirrhosis of the liver by a nutritious diet and supplements rich in vitamin B complex. J. Clin. Invest., 1941, $20,481$.

2. Lyttle, J. D., Goettsch, E., Greeley, D. M., Grim, W. M., and Dunbar, P., Amino acid studies. II. Plasma amino acid retention, as evidence of impaired liver function. Investigations in children with nephrosis and liver disease. J. Clin. Invest., 1943, 22, 169.

3. Brunschwig, A., Clark, D. E., and Corbin, N., Symposium on abdominal surgery; postoperative nitrogen loss and studies on parenteral nitrogen nutrition by means of casein digest. Ann. Surg., 1942, 115, 1091.

4. Bernhart, F. W., and Schneider, R. W., A new test of liver function-the tyrosine tolerance test. Am. J. Med. Sc., 1943, 205, 636.

5. Council on Pharmacy and Chemistry, Report. Protein Hydrolysates. J. A. M. A., 1948, 136, 693.

6. Kirk, E., Amino acid and ammonia metabolism in liver diseases. Acta med. Scandinav., Suppl., 1936, 77, 1. 7a. Stewart, J. D., and Rourke, G. M., Changes in blood and urine after intravenous amino acid mixture in patients with liver disease. Proc. Soc. Exper. Biol. \& Med., 1942, 51, 364.

b. Stewart, J. D., Hale, H. W., Jr., and Schaer, S. M., Management of protein deficiency in surgical patients. J. A. M. A., 1948, 136, 1017.

8. Hecht, H. H., Reactions to intravenously administered amino acids (casein hydrolysates). Am. J. Med. Sc., 1946, 212, 35.

9. Lewis, J. H., Taylor, F. H. L., and Davidson, C. S., Tolerance to intravenously administered protein hydrolysate in severe human liver cirrhosis. Am. J. Med. Sc., 1947, 214, 656.

10. Fagin, I. D., and Zinn, F. T., Cirrhosis of the liver. Results of treatment with parenterally administered amino acids. J. Lab. \& Clin. Med., 1942, 27, 1400.

11. Capps, R. B., and Barker, M. H., The management of infectious hepatitis. Ann. Int. Med., 1947, 26, 405.

12. Davidson, C. S., Chalmers, T. C., Faloon, W. W., Murphy, T. L., and Eckhardt, R. D., The treatment of chronic liver disease. Univ. West. Ontario M. J., 1948, 18, 47.

13. Eckhardt, R. D., Lewis, J. H., Murphy, T. L., Batchelor, W. H., and Davidson, C. S., Chemical, clinical and immunological studies on the products of human plasma fractionation. XXXIV. Comparative studies on the nutritive value of orally and intravenously administered human serum albumin in man. J. Clin. Invest., 1948, 27, 119.

14. Rose, W. C., The role of the amino acids in human nutrition. Proc. Am. Philos. Soc., 1947, 91, 112.

15. Stokes, J. L., Gunness, M., Dwyer, I. M., and Caswell, M. C., Microbiological methods for the determination of amino acids. II. A uniform assay for the ten essential amino acids. J. Biol. Chem., $1945,160,35$.

16. Larson, P. S., and Chaikoff, I. L., The influence of carbohydrate on nitrogen metabolism in the normal nutritional state. J. Nutrition, 1937, 13, 287.

17. Hamilton, P. B., and Van Slyke, D. D., The gasometric determination of free amino acids in blood filtrates by the ninhydrin-carbon dioxide method. J. Biol. Chem., 1943, 150, 231.

18. Van Slyke, D. D., MacFadyen, D. A., and Hamilton, P. B., The gasometric determination of amino acids in urine by the ninhydrin-carbon dioxide method. J. Biol. Chem., 1943, 150, 251.

19. Folin, O., Laboratory Manual of Biological Chemistry with Supplement. Appleton-Century, New York, 1934, Ed. 5, p. 265.

20. Ducci, H., and Watson, C. J., The quantitative determination of the serum bilirubin with special reference to the prompt-reacting and the chloroformsoluble types. J. Lab. \& Clin. Med., 1945, 30, 293.

21. Ley, A. B., Lewis, J. H., and Davidson, C. S., The quantitative determination of the thymol turbidity reaction of serum. J. Lab. \& Clin. Med., 1946, 31, 910 . 
22. Howe, P. E., The use of sodium sulfate as the globulin precipitant in the determination of proteins in blood. J. Biol. Chem., 1921, 49, 93.

23. Keys, A., A rapid micro-Kjeldahl method. J. Biol. Chem., 1940, 132, 181.

24. MacFadyen, D. A., Determination of amino acids in plasma by the ninhydrin-carbon dioxide reaction without removal of proteins. J. Biol. Chem., 1942, $145,387$.

25. Eckhardt, R. D., and Davidson, C. S., Urinary excretion of amino acids by a normal adult receiving diets of varied protein content. J. Biol. Chem., 1949, 177, 687.

26. Grabfield, G. P., and Prescott, B., Nitrogen and sulfur metabolism in Bright's disease. VIII. Effect of ingestion of urea on nitrogen excretion and sulfur partition in nephrosis, glomerulonephritis and cirrhosis of liver. Arch. Int. Med., 1937, 59, 823.

27. Post, J., and Patek, A. J., Jr., Serum proteins in cirrhosis of the liver. II. Nitrogen balance studies on five patients. Arch. Int. Med., 1942, 69, 83.

28. Eckhardt, R. D., and Davidson, C. S., The rapid injection of a solution of amino acids. A note on its clinical tolerance in man. New England J. Med., 1948, 239, 164.

29. Robscheit-Robbins, F. S., Miller, L. L., and Whipple, G. H., Plasma protein and hemoglobin production. Deletion of individual amino acids from growth mixtures of ten essential amino acids. Significant changes in urinary nitrogen. J. Exper. Med., 1947, 85, 243.

30. Peters, J. P., and Van Slyke, D. D., Quantitative Clinical Chemistry. Interpretations. Baltimore, 1946, Volume I, Ed. 2, p. 656.

31. Madden, S. C., Bassett, S. H., Remington, J. H., Martin, F. J. C., Woods, R. R., and Shull, F. W., Amino acids in therapy of disease. Parenteral and oral administrations compared. Surg., Gynec. \& Obst., 1946, 82, 131.

32. Eckhardt, R. D., and Davidson, C. S., The oral and parenteral phenylalanine requirements for nitrogen equilibrium in man. J. Clin. Invest., 1948, 27, 165.

33. Faloon, W. W., Eckhardt, R. D., Cooper, A. M., and Davidson, C. S., The effect of human serum albumin, mercurial diuretics, and a low sodium diet on sodium excretion in patients with cirrhosis of the liver. J. Clin. Invest., 1949, 28, 595.

34. Eckhardt, R. D., Cooper, A. M., Faloon, W. W., and Davidson, C. S., The urinary excretion of amino acids in man. Tr. New York Acad. Sc., 1948, 10, 284.

35. Eckhardt, R. D., and Davidson, C. S., Urinary excretion of amino acids following the rapid injection of a solution of amino acids in man. J. Clin. Invest., 1948, 27, 727.

36. Vars, H. M., and Gurd, F. N., Effect of dietary protein upon the regeneration of liver protein in the rat. Am. J. Physiol., 1947, 151, 399.

37. Whipple, G. H., Hemoglobin and plasma proteins : their production, utilization and interrelation. Am. J. Med. Sc., 1942, 203, 477.

38. Heath, C. W., and Taylor, F. H. L., The nitrogen metabolism in anemia during the regeneration of blood. J. Clin. Invest., 1936, 15, 411.

39. Kobak, M. W., Benditt, E. P., Wissler, R. W., and Steffee, C. H., The relation of protein deficiency to experimental wound healing. Surg., Gyn. \& Obst., 1947, 85, 751.

40. Myers, W. K., and Keefer, C. S., Relation of plasma proteins to ascites and edema in cirrhosis of the liver. Arch. Int. Med., 1935, 55, 349.

41. Lewis, J. H., Taylor, F. H. L., and Davidson, C. S., Protein nutrition. The therapeutic use of a digest of liver protein, especially in patients with cirrhosis of the liver. New Eng. J. Med., 1947, 236, 351. 